\title{
Semantika produk kacamata dan hubungannya dengan pencitraan kader politik
}

\author{
Abbyzar Raffi Hernawan, ${ }^{1 *}$ Achmad Syarief ${ }^{2}$ \\ ${ }^{1,2}$ Program Studi Magister Desain FSRD, Institut Tteknologi Bandung, Indonesia
}

\begin{abstract}
Daily use objects form someone's self-image as it mark the appearance of identify, life style and character of a person. Therefore, owned and used objects hold a role of persuasion tool. This well-aware knowledge is deliberately used in political campaign such as posters, baliho, and banners which present image of a political candidate. The appeal of blazer, shirts, eyeglasses, moslem hijab and cap, serves as means to develop self-image and character, especially when it is amplify competent image of an intellectual that hold leadership, and honesty. Using semanic differential method, the research analyze varieties of type, forms/shapes, and physical measurement of eyeglasses; in order to understand perceptual varieties of self-image that openly appear in public
\end{abstract}

Key words: semantics, glasses, self image, politics

\begin{abstract}
Abstrak
Pemakaian objek dalam kehidupan sehari- hari membentuk citra diri seseorang, serta menjadi penanda munculnya identitas, gaya hidup, dan sifat seseorang. Dengan demikian obyek yang dimiliki dan digunakan sesungguhnya berperan sebagai alat persuasi. Hal ini disadari dan dimanfaatkan dalam kampanye politik seperti poster, spanduk atau baliho yang menampilkan foto/Gambar kader partai politik. Tampilan blazer, kemeja, kacamata, jilbab, dan peci menjadi sebuah 'kredo' untuk membangun citra dan imej diri sebagai pengerek elektabilitas. Berdasarkan premis tersebut, penelitian ini mengkaji penggunaan obyek kacamata pada foto/Gambar wajah kader partai politik dan hubungannya dengan pembentukan citra diri. Sebagai obyek penelitian, kacamata memiliki makna stereotip yang terkait kompetensi dan karakter imej seseorang, khususnya citra intelektual, kepemimpinan, dan kejujuran. Dengan metode identifikasi semantik diferensial, penelitian ini melakukan analisa atas berbagai tipe, bentuk, dan ukuran fisik kacamata untuk memahami variasi persepsi responden terhadap pembentukan citra diri seseorang yang tampil di ruang publik.
\end{abstract}

Kata kunci: semantika, kacamata, citra diri, politik

\section{Pendahuluan}

Setelah berselang lima tahun dari pesta demokrasi di tahun 2014, pada tahun 2019 pesta demokrasi memasuki babak baru dengan diselenggarakannya pemilihan umum (pemilu). Banyaknya jumlah caleg mengakibatkan setiap caleg perlu melakukan kampanye dan membangun citra diri yang positif sehingga meningkatkan elektibilitas. Di setiap sisi jalan terpajang media visual yang menampilkan foto, logo partai, slogan dan visi misi caleg. Jenis objek yang digunakan oleh para caleg pada media kampanye sangatlah beragam. Berdasarkan hasil observasi, objek yang biasa digunakan oleh para caleg adalah peci, jilbab, perlengkapan militer, baju adat, blazer, kemeja, dasi dan kacamata. Objek-objek tersebut umumnya mengarahkan pada image relijius, berbudaya, nasionalis, formalitas dan intelektualitas. Namun dari setiap objek pencitraan ini, objek kacamata menjadi perhatian dalam penelitian ini.

Dalam penelitian psychology (Thornton, 1943), kacamata memberikan pengaruh terhadap penilaian sosial pada seorang individu. Penelitian mengemukakan bahwa seseorang yang menggunakan kacamata menerima efek positif dalam penilaian sosial seperti: tingginya intelektualitas, dapat

\footnotetext{
* Corresponding author Tel : +085871922283; e-mail : annuitterra@gmail.com
} 
dipercaya, pekerja keras, dan jujur. Namun tidak selamanya kacamata memberikan makna positif, terdapat beberapa penelitian yang menunjukkan efek negatif penggunaan kacamata seperti keterkaitan dengan rendahnya popularitas pada pengguna kacamata. (Elman, 1977) dan asosiasi karakteristik berkurangnya kekuatan pada pengguna kacamata. (Terry dan Krantz, 1993).

Fenomena pengunaan kacamata sebagai media dalam konstruksi citra diri caleg ditunjukan oleh kampanye pasangan walikota Bandung yaitu Ridwan Kamil dan Oded di tahun 2015. Pada periode kampanye tersebut, pasangan Ridwan Kamil dan Oded menunjukkan pola yang menarik dalam rekonstruksi sosial, pasangan ini menggunakan icon kacamata pada logo kampanye mereka. Penggunaan icon kacamata tidak hanya di aplikasikan ke logo pasangan, namun diaplikasikan juga pada 12 modifikasi logo-logo yang beragam mewakili semangat kota bandung meliput : $3 G$, brave, creative, fun, futuristic, hero, hip, imagine, justice, loyal, wise, dan RK BDG sebagai logo utama. Ridwan Kamil tidak hanya terfokus pada kemampuanya dalam mengolah kemampuan dalam menata kota namun juga menata sebuah citra, dari fenomena ini terlihat bahwa objek kacamata dijadikan sebagai sebuah strategi personal brand dalam memunculkan sosok pemimpin yang iconic dan ideal di mata masyarakat.

Fenomena pencitraan ini kemudian berlanjut pada kampaye calon walikota Bandung di tahun 2019. Muncul sebuah pola keseragaman pada penampilan beberapa Bakal Calon Walikota yaitu menggunakan ornamentasi kacamata. Dari sekitar 16 orang bakal calon walikota terdapat 10 orang yang menggunakan kacamata dan sisanya 6 orang tidak menggunakan kacamata. Muncul sebuah asumsi bahwa para bakal calon walikota mencoba meniru atau mereplikasi sosok Ridwan Kamil dengan menggunakan kacamata. Hal ini menunjukkan bahwa kacamata tidak hanya berfungsi sebagai alat bantu melihat, namun juga alat bantu untuk dilihat.

Menurut Stewart L.Tubbs dan Sylvia Moss (1958) dalam buku Human Communication "Cara berpakaian, Berdandan, dan penampilan fisik seringkali menjadi dasar bagi kesan pertama, yang relative bertahan lama. Bahkan kacamata dapat mempengaruhi persepsi orang lain terhadap pemakainnya”. Dalam beberapa penelitian, orangorang menerima bantuan yang lebih besar atau permohonannya lebih mudah dikabulkan (misalnya, untuk menandatangani petisi) bila mereka berpakaian resmi atau rapih dari pada bila mereka berpakaian biasa atau serampangan.

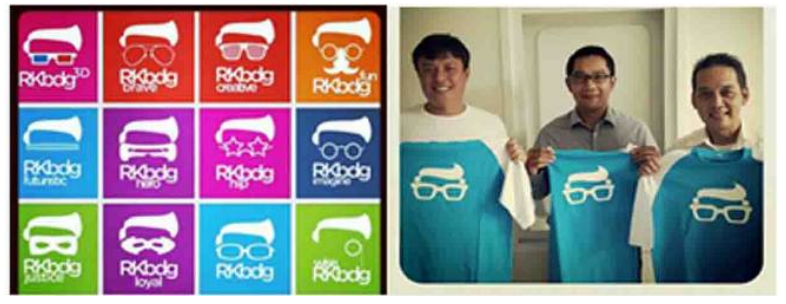

Gambar 1. Logo kampanye Ridwan Kamil (Sumber: http://instagram.com/ridwankamil)
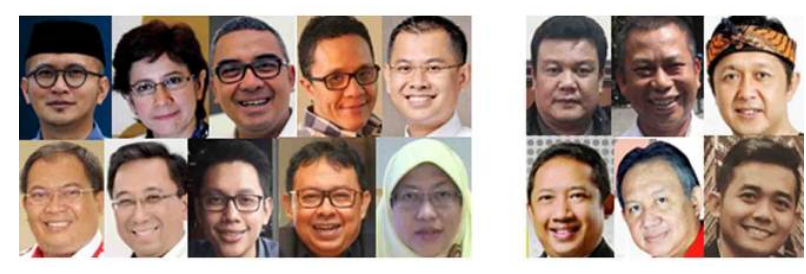

Gambar 2. Bakal calon walikota Bandung 2019 (Sumber: Penulis)

Pembentukan citra diri seorang caleg (calon legislatif) dapat mempengaruhi elektabilitas, sehingga dengan beragamnya variasi kacamata, maka perlu diketahui jenis kacamata yang ideal dalam membentuk citra kepemimpinan. Penelitian ini bertujuan untuk mengidentifikasi jenis-jenis kacamata yang digunakan oleh para caleg dan citra diri yang terbentuk dari penggunaannya, Memahami hubungan antara bentuk kacamata dan tipe wajah dalam membentuk citra diri, dan dapat mengklasifikasikan jenis kacamata yang ideal dalam membentuk citra kepemimpinan.

\section{Bahan dan metode}

Objek penelitian ini adalah kacamata yang digunakan oleh para caleg saat kampanye pemilu calon legislatif 2019. Para caleg yang diobservasi, tefokus pada caleg di dapil 1-11 Jawa barat. Jumlah caleg yang menggunakan kacamata berjumlah 114 orang, yang terdiri dari 26 orang wanita dan 88 orang pria. Terdapat 6 jenis kacamata yang digunakan oleh para caleg, yaitu: kacamata frame kotak (square) dengan persentase pria-42,0\% dan wanita-34,6\%, frame persegi panjang (rectangle) dengan persentase pria-27,3\% dan wanita-19,2\%, frame bentuk-D ( $D$ shaped) dengan persentase pria-10,3\% dan wanita$19,2 \%$, frame lonjong (oval) persentase pria-12,5\% dan wanita-7,7\%, frame bulat (round) dengan persentase pria-8,0\% dan wanita- $0 \%$, dan frame mata kucing (cat eye) dengan persentase pria-0 \% dan wanita-19,2\%. Mayoritas caleg pria dan wanita menggunakan kacamata dengan bentuk frame square 
Abbyzar Raffi Hernawan, Achmad Syarief

dan rectangle. Tidak ditemukan pengguna kacamata frame cateye pada caleg pria, sedangkan pada caleg wanita tidak ditemukan pengguna kacamata frame round. Gambar 3 memperlihatkan persentase jenis kacamata pada caleg dapil 1-11 Jawa Barat.

Wajah adalah daerah utama kacamata digunakan sehingga tipe wajah memiliki kemungkinan mempengaruhi citra yang terbentuk dari penggunaan kacamata. Oleh sebab itu untuk mengetahui hubungan tersebut maka dilakukan perhitungan tipe wajah caleg menggunakan perhitungan facial index yang mengacu facial index Martin\& Saller (1957). yang ditunjukan pada Gambar 4.
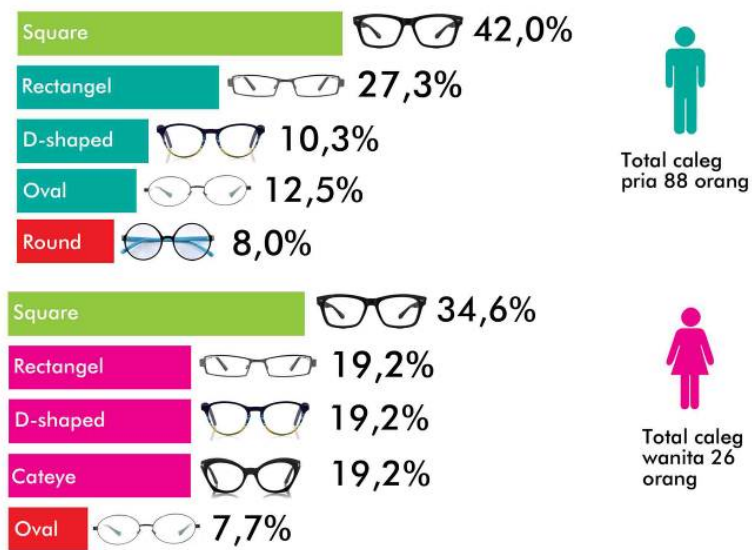

Gambar 3. Persentase jenis kacamata pada caleg dapil 1-11 Jawa Barat (Sumber: Penulis)

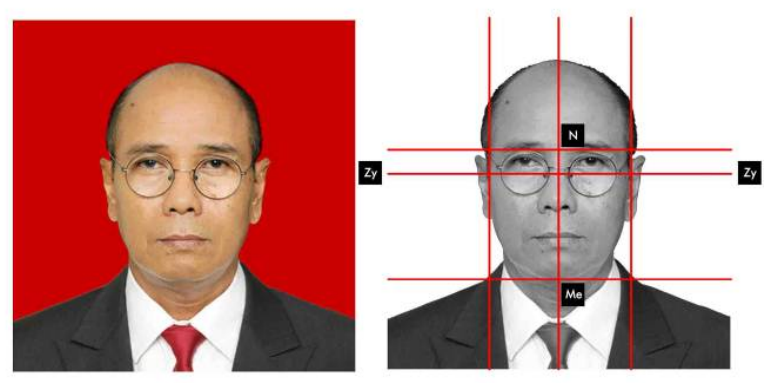

Gambar 4. Metode perhitung tipe wajah caleg (Sumber: Penulis)

$$
\text { Facial Index : } \frac{\text { Morphological Facial Height (N-Gn) x } 100}{\text { Bizygomatic width (Zyr - Zyl) }}
$$
N-Gn : 3,3
Zyr-Zyl : 3,6
$\mathrm{Fi}: \frac{3,3 \times 100}{3,6}$
FACIAL INDEX : 91,6 (LEPTOPROSOPIC)

Tabel 1. Klasifikasi tipe wajah berdasarkan indeks facialis

\begin{tabular}{lcc}
\hline \multicolumn{1}{c}{ Tipe Wajah } & Laki-laki & Perempuan \\
\hline $\begin{array}{l}\text { Hypereuryprosop (wajah lebih pendek } \\
\text { atau lebar) }\end{array}$ & $\mathrm{x}-78,9$ & $\mathrm{x}-76,8$ \\
Euryprosop (wajah pendek atau lebar) & $79,0-83,9$ & $77,0-80,9$ \\
Mesoprosop (wajah sedang) & $84,0-87,9$ & $81,0-84,9$ \\
Leptoprosop (wajah tinggi atau sempit) & $88,0-92,9$ & $85,0-89,9$ \\
Hyperleptoprosop (wajah lebih tinggi atau & $93,0-\mathrm{x}$ & $90,0-\mathrm{x}$ \\
sempit) & & \\
\hline
\end{tabular}

Sumber: Martin \& Saller (1957)

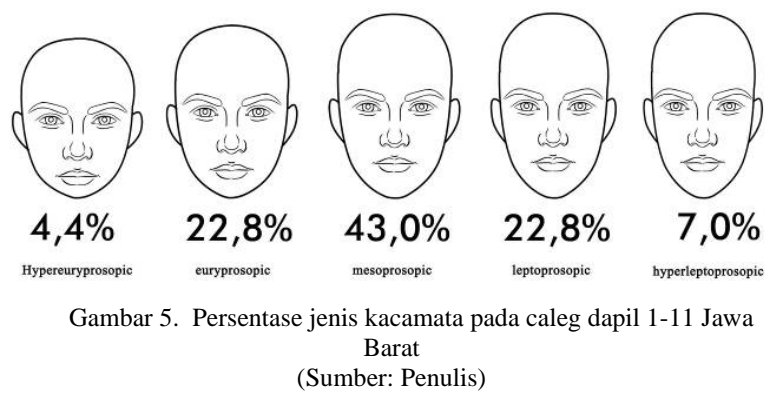

Foto caleg yang diukur adalah foto wajah frontal yang didapatkan dari surat suara yang dikeluarkan oleh Komisi Pemilihan Umum (KPU). Setiap foto caleg diukur menggunakan perangkat lunak Photoshop CS3 dengan mengukur jarak dari titik tengah pangkal hidung ( $\mathrm{N}-\mathrm{Gn})$ sampai titik paling bawah dagu kemudian dikali 100 dan dibagi dengan jarak titik paling pinggir pada lengkungan zygomaticum (Zyr-Zyl), sehingga menghasilkan nilai facial index. Setelah wajah caleg diukur, maka nilai facial index dapat diklasifikasikan sesuai dengan nilai di Tabel 1 facial index Martin \& Saller. Sehingga tipe wajah caleg dapat diketahui.

Berdasarkan hasil perhitungan pada 114 wajah caleg, diketahui terdapat lima tipe wajah. Jika dilihat dari persentasenya pada Gambar 5, caleg bertipe wajah hypereuryprosopic (4,4\%), dan hyperleptoprosopic $(7,0 \%)$ memiliki jumlah yang sedikit, sedangkan tipe wajah yang dominan adalah tipe euryprosopic (wajah pendek/lebar-22,8\%), mesoprosopic (wajah sedang-43,0\%), dan leptoprosopic (wajah panjang/ sempit-22.8\%). Sehingga pada penelitian ini hanya tipe wajah dominan yang diteliti hubunganya dengan frame kacamata.

Penelitian ini mencoba menjabarkan fenomena sosial terkait pembentukan citra diri melalui penggunaan sebuah produk. Proses pengumpulan data dilakukan dengan metode survey dengan menggunakan instrumen kuesioner semantic differential (SD). Krippendorff (2006:159) menjelaskan bahwa metode pertama dan yang paling 
dikenal untuk mengkonseptualisasi karakter berasal dari Osgood et al (1957). Semantic differential adalah instrumen yang bergantung pada sejumlah sampel informan yang besar, subjek atau para pemangku kepentingan yang secara individual menilai sebuah objek atau konsep dalam skala kata sifat bipolar. Kata sifat yang digunakan kemudian dikategorisasi ke dalam dimensi EPA, meliputi dimensi evaluasi, dimensi potensi, dan dimensi aktifitas. Pada tahapan awal peneliti melakukan survey untuk menyusun kata sifat dengan mengumpulkan 100 opini masyarakat yang terdiri dari 50 pria dan 50 wanita. Opini ini terkait dengan sifat-sifat pemimpin yang ideal. Kata sifat ini kemudian di ranking dan diseleksi 9 kata sifat paling dominan yang mewakili sifat kepemimpinan. Kemudian setiap kata sifat digunakan sebagai skala semantic differential yang disusun dalam bentuk pasangan kata sifat bipolar seperti yang ditunjukkan pada Tabel 2, kata sifat ini meliputi: canggungnyaman, bodoh-pintar, kasual-formal, bohong-jujur, rumit-sederhana, kasar-halus, egois-peduli, lembuttegas, dan lamban-cekatan.

Setelah objek penelitian ditentukan maka penelitian dilanjutkan dengan perancangan instrumen penelitian berupa kuesioner Semantic differential, sehingga dilakukan uji pilot untuk menguji validitas dan reliabilitas instrumen. Uji validitas adalah untuk menguji tingkat kevalidan instrumen kuesioner yang digunakan untuk mengumpulkan data. Uji validitas ini dilakukan untuk mengetahui apakah item-item yang disajikan pada kuesioner benar benar mampu mengungkapkan dengan hasil pasti apa yang akan diteliti atau diukur. Dalam penelitian ini menggunakan nilai $\mathrm{r}$ hasil Corrected Item Total Correlation melalui sub menu scale dari perhitungang dengan program SPSS rumus yang digunakan dalam uji validitas ini dengan cara membandingkan nilai correlated item total correlation (r) hitung yang harus lebih besar dari nilai $r$-table product moment Pearson pada alpha $=0,05$ (Indriantoro, $\mathrm{N}$ dan Supomo, B.(1999:40).

Tabel 3 merupakan hasil uji validitas instrumen kuesioner dari jumlah sampel 60 orang, pengujian ini bertujuan untuk menguji validitas setiap poin pertanyaan yang terdapat pada kuesioner. Pada kuesioner terdapat 9 pertanyaan dan hasil menunjukkan 9 pertanyaan dinyatakan valid karena nilai $\mathrm{r}$ hitung positif, serta $\mathrm{r}$ hitung $>r$ table alpha $=$ $0,05 \mathrm{df} n-2$ dengan taraf signifikasi $95 \%$.

Uji reliabilitas dipakai untuk membuktikan konsistensi suatu alat ukur. Sebuah alat ukur dikatakan reliable apabila dalam beberapa kali pengukuran terhadap kelompok atau subjek yang

Tabel 2. Kata-kata sifat yang termasuk kedalam dimensi EPA

\begin{tabular}{cccc}
\hline No & Evaluative & Potency & Activity \\
\hline 1 & Canggung-Nyaman & Bodoh-Pintar & Kasual-Formal \\
2 & Egois-Peduli & Rumit-Sederhana & Lamban-Cekatan \\
3 & Bohong-Jujur & Lembut-Tegas & Kasar-Halus \\
\hline
\end{tabular}

Sumber: Penulis

Tabel 3. Nilai uji validitas product moment Pearson

\begin{tabular}{llc}
\hline No & \multicolumn{1}{c}{ Variable } & Pearson correlation \\
\hline 1 & Canggung - nyaman & 0,613 \\
2 & Bodoh - pintar & 0,482 \\
3 & Kasual - formal & 0,367 \\
4 & Bohong - jujur & 0,466 \\
5 & Rumit - sederhana & 0,608 \\
6 & Kasar - halus & 0,356 \\
7 & Egois - peduli & 0,460 \\
8 & Lembut - tegas & 0,378 \\
9 & Lamban - cekatan & 0,325 \\
\hline
\end{tabular}

Sumber: SPSS

Tabel 4. Nilai uji reliabilitas instrumen Croncbach Alpha
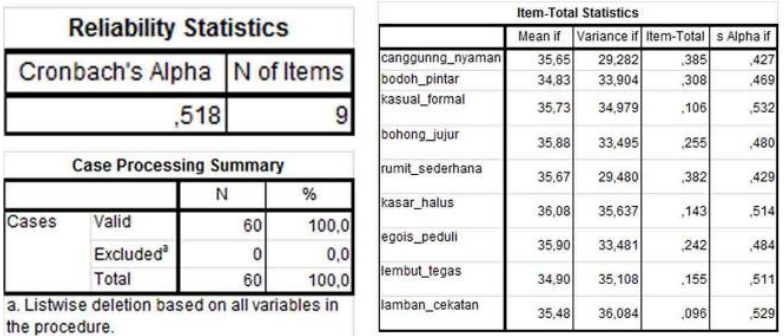

Sumber: SPSS.

sama diperoleh hasil yang relatif sama. Uji reliabilitas menggunakan metode Alpha Cronchbach dengan cara membandingkan nilai alpha dengan r-table (Husein Umar (2003:125).

Tabel 4 merupakan hasil uji reliabilitas instrumen penelitian dari jumlah sampel N: 60 orang. Pengujian ini bertujuan untuk melihat konsistensi alat ukur yang digunakan. Nilai cronbach's Alpha pada penelitian ini adalah 0,518 sehingga dinyatakan cukup reliabel karena berada pada rentang nilai alpha 0,41-0,60 reliabilitas.

Peneliti mencari 60 responden yang terdiri dari 30 pria dan 30 wanita. Kuesioner menggunakan kertas berukuran A4 dengan jumlah tiga lembar. Disetiap lembar terdapat ilustrasi satu jenis tipe wajah yang dipasangakan dengan enam jenis kacamata yang berbeda. Responden diarahkan untuk mengisi data demografis dan menilai setiap objek penelitian dengan menceklis skala 1-7 pada setiap pasang kata sifat bipolar. Jumlah pertanyaan yang diberikan pada responden berjumlah 162 poin. Hasil penilaian responden kemudian dibentuk ke dalam grafik dilihat alur paling dominan di setiap kata sifat. Sehingga mendapatkan pengukuran dimensi EPA, dan 
Abbyzar Raffi Hernawan, Achmad Syarief

menunjukkan kecenderungan persepsi pada setiap variabel secara mandiri.

Tahapan kedua survey dilakukan dengan menyebarkan kuesioner semantic differential. Grafik semantic differential terdiri atas grafik yang menunjukkan perbandingan persepsi general pada enam jenis kacamata berdasarkan penilaian 60 responden dan persepsi berdasarkan gender, meliputi penilaian 30 orang pria dan 30 orang wanita. Hasil analisa alur grafik SD merupakan evaluasi awal yang kemudian dilanjutkan pada analisa faktor menggunakan metode principal component analysis dengan prosedur statistik. Pada penelitian ini tujuan digunakannya analisis faktor bersifat exploratif yaitu mendeteksi suatu pola dari variabel dengan tujuan untuk menemukan faktor baru sehingga faktor baru ini dapat dipetakan kedalam bentuk plot matrix. Pemetaan ini berfungsi untuk mengetahui persebaran persepsi dominan pada setiap kacamata, sehingga dapat diketahui jenis kacamata dan tipe wajah yang ideal dalam membentuk citra kepemimpinan.

\section{Hasil dan pembahasan}

\section{Alur persepsi responden pada 6 jenis kacamata}

Pada Gambar 6 alur grafik semantic menunjukkan arah kata sifat pada enam jenis frame kacamata meliputi: rectangle / persegi panjang (merah), $D$ shaped / bentuk D (kuning), cateye / mata kucing (hijau), oval / lonjong (biru), round / bulat (pink), dan square / kotak (orange). Grafik semantic differential ini dihasilkan dari hasil score rata-rata 60 responden.

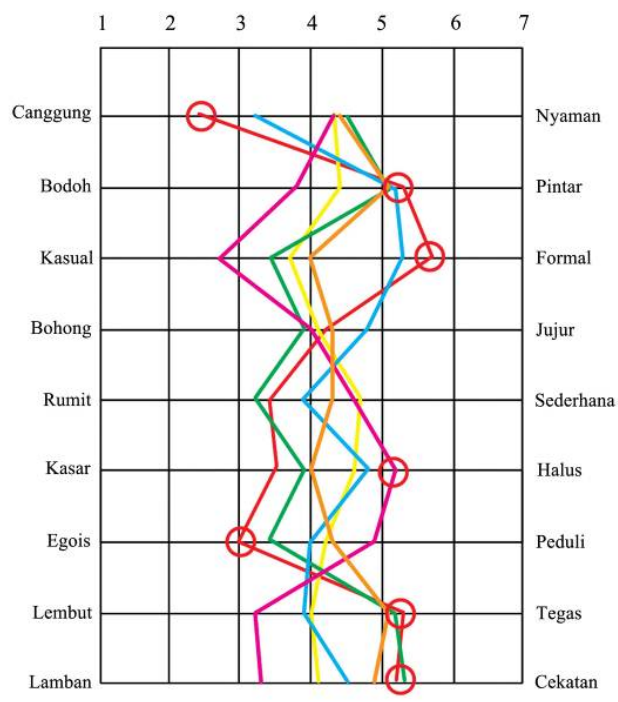

Gambar 6. Alur grafik semantic differential pada 6 jenis kacamata berdasarkan penilaian 60 responden. (Sumber: Penulis)
Terdapat tujuh kata sifat paling dominan yang muncul yaitu: canggung $(2,4)$, pintar $(5,3)$, formal $(5,7)$, halus $(3,5)$, egois (3), tegas $(5,3)$ dan cekatan $(5,2)$. Kacamata bentuk rectangle memiliki penilaian yang paling dominan terbanyak (5 kata sifat), meliputi: canggung, pintar, formal, egois, dan tegas. Pada alur kata sifat halus, titik paling dominan berada pada kacamata round $(5,2)$. Sedangkan pada alur kata sifat cekatan, titik paling dominan berada pada kacamata cat eye $(5,3)$. Kacamata jenis D-shaped, oval, dan square berada pada wilayah netral. Kata sifat berkonotasi positif lebih dominan (5 kata sifat) daripada kata sifat berkonotasi negatif (2 kata sifat).

Dari enam jenis kacamata, terdapat empat kacamata yang dipersepsi paling dominan oleh responden yaitu kacamata jenis rectangle, cateye, round dan oval. Berdasarkan Tabel 6, kacamata rectangle adalah kacamata paling dominan dipersepsi oleh responden. Kacamata jenis rectangle mengarah pada kata sifat positif dan negatif, sedangkan kacamata oval, round, dan cateye hanya mengarah pada kata sifat positif.

Dari enam jenis kacamata yang ditampilkan pada Tabel 7, empat jenis kacamata dipersepsi lebih dominan oleh responden, meliputi kacamata rectangle, cateye, round, dan oval. Sedangkan kacamata $D$-shaped dan square persepsi cenderung netral.

Tabel 6. Kata sifat bermuatan positif dan negatif pada kacamata yang dipersepsi paling dominan

\begin{tabular}{ccc}
\hline Kacamata & Kata sifat $(+)$ & Kata sifat $(-)$ \\
\hline Rectangle & pintar,formal,tegas,cekatan & Canggung,egois \\
Oval & Pintar & - \\
Round & Halus & - \\
Cateye & Tegas,cekatan & - \\
\hline
\end{tabular}

Sumber: Penulis.

Tabel 7. Jenis kacamata yang dipersepsi dominan dan tidak dominan

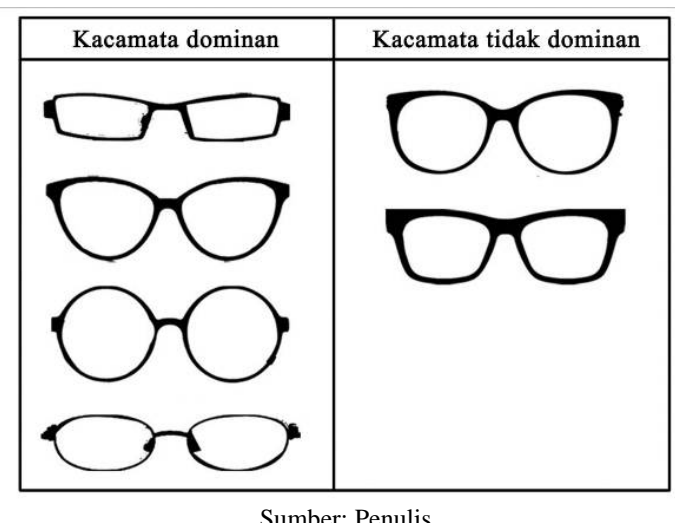

Sumber: Penulis 


\section{Alur persepsi pria pada 6 jenis kacamata}

Gambar 7 menunjukkan alur persepsi pada gender pria, jenis kacamata yang dipersepsi secara kuat berjumlah 3 kacamata meliputi jenis rectangle, oval, dan round. Terdapat 7 kata sifat yang muncul paling dominan pada penilaian pria meliputi: canggung, pintar, formal, halus, egois, tegas dan cekatan.

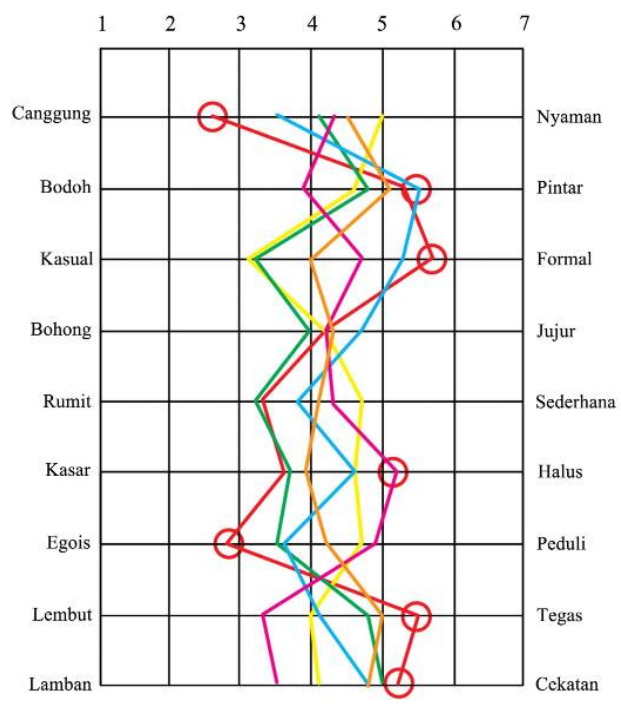

Gambar 7. Alur grafik semantic differential pada 6 jenis kacamata berdasarkan penilaian pria (Sumber: Penulis)

Tabel 8. persepsi pria pada 6 jenis kacamata.

\begin{tabular}{ccc}
\hline Kacamata & Kata sifat $(+)$ & Kata sifat $(-)$ \\
\hline Rectangle & formal,tegas,cekatan & Canggung,egois \\
Oval & Pintar & - \\
Round & Halus & - \\
\hline \multicolumn{3}{c}{}
\end{tabular}

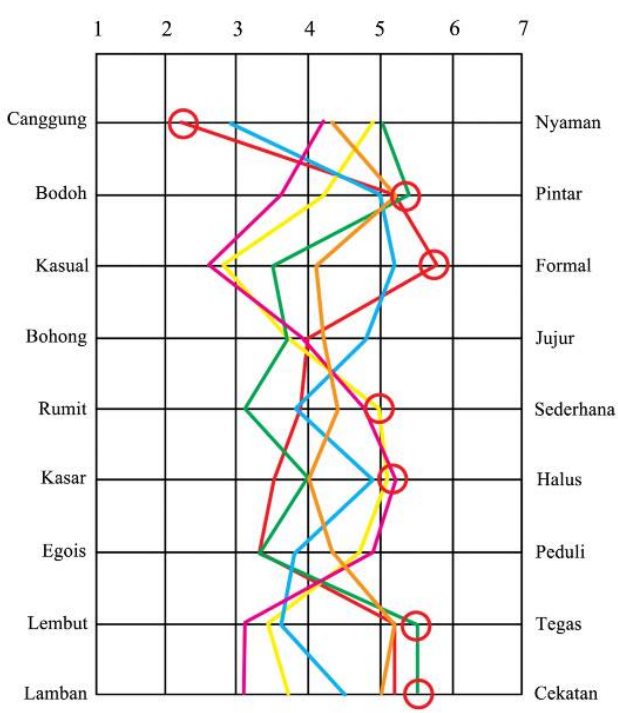

Gambar 8. Alur grafik semantic differential pada 6 jenis kacamata berdasarkan penilaian wanita. (Sumber : Penulis).
Tabel 9. Jenis kacamata yang dominan di kedua gender

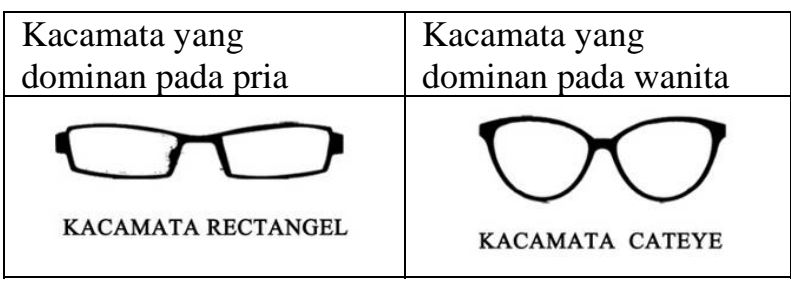

Sumber : Penulis

Kacamata jenis rectangle dipersepsi paling dominan oleh gender pria. Terdapat 5 jenis kata sifat dominan pada kacamata rectangle yaitu : canggung $(2,6)$, formal $(5,7)$, egois $(2,8)$, tegas $(5,5)$ dan cekatan $(5,2)$. Kacamata oval mengarah pada kata sifat dominan pintar $(5,5)$ sedangkan kacamata round pada kata sifat halus $(5,2)$. Kacamata jenis D-shaped, cat eye dan square berada pada wilayah netral. Pria memiliki kata sifat dominan positif lebih banyak (5 kata sifat) daripada kata sifat dominan negatif (2 kata sifat). Sehingga menunjukkan bahwa persepsi pria pada kacamata cenderung positif.

\section{Alur persepsi wanita pada 6 jenis kacamata}

Pada gender wanita, jenis kacamata yang dipersepsi secara dominan berjumlah 4 frame meliputi jenis rectangle, D-shaped, cat eye, dan round. Terdapat 7 kata sifat yang muncul paling dominan pada penilaian wanita meliputi: canggung, pintar, formal, sederhana, halus, tegas, dan cekatan.

Kacamata jenis cat eye dipersepsi paling dominan oleh gender wanita. Pada Gambar 8 terdapat 3 jenis kata sifat dominan pada kacamata cat eye yaitu: pintar $(5,4)$, tegas $(5,5)$ dan cekatan $(5,5)$. Pada kacamata rectangel terdapat 2 kata sifat dominan yaitu canggung $(2,2)$, dan formal $(5,8)$. Kacamata $D$-shaped dan round memiliki jumlah kata sifat dominan yang sama-sama berjumlah 1 kata sifat, namun memiliki perbedaan sifat. Kacamata $D$-shaped mengarah pada sifat sederhana (5), sedangkan kacamata round mengarah pada kata sifat halus $(5,2)$. Kacamata jenis oval dan square berada pada wilayah netral. Wanita memiliki kata sifat dominan positif lebih banyak (6 kata sifat) daripada kata sifat dominan negatif (1 kata sifat). Sehingga persepsi wanita pada kacamata cenderung positif.

Persepsi kedua gender pada objek kacamata menunjukkan bahwa, jenis kacamata yang dipersepsi paling dominan dan positif oleh wanita adalah jenis cateye, sedangkan pria adalah kacamata jenis rectangle. Gender pria lebih dominan menilai kacamata dengan karakteristik frame sempit sedangkan wanita lebih dominan pada kacamata frame lebar. Persepsi wanita pada kacamata lebih 
Abbyzar Raffi Hernawan, Achmad Syarief

dominan dan bervariasi daripada pria, sehingga gender wanita lebih sensitif dalam menilai kacamata.

Analisa alur grafik semantic differential, menunjukkan bahwa perbedaan gender memperlihatkan adanya perbedaan persepsi terhadap kacamata. Secara general keseluruhan gender menilai kacamata membentuk citra yang positif namun berbeda preferensi bentuk frame.

\section{Principal component analysis}

Untuk mengetahui persepsi yang terbentuk pada setiap bentuk kacamata, maka dilakukan principal component analysis. Analisa ini dilakukan untuk menyederhanakan variabel sehingga membentuk faktor baru yang mendasari terbentuknya sebuah persepsi. Proses PCA dilakukan pada enam jenis kacamata pada 3 tipe wajah. Analisa PCA terdiri dari Mengukur kecukupan sampling / sampling adequancy menggunakan Kaiser Meyer Olkin Measure of Sampling (KMO), Menentukan jumlah faktor yang dapat terbentuk dengan mengukur nilai eigenvalue pada total variance explain, merotasi component matrix menggunakan metode varimax, dan melakukan pemetaan dalam bentuk plot matrix. Berikut contoh dari PCA pada analisa persepsi kacamata rectangle.

Tabel 10. KMO dan Bartlletts test kacamata rectangle di tiga tipe wajah

KMO and Bartlletts test ( euryprosopic )

\begin{tabular}{|l|r|r|}
\hline Kaiser-Meyer-Olkin Measure of Sampling Adequacy. &, 583 \\
Bartlett's Test of Sphericity & Approx. Chi-Square & 91,747 \\
& df & 36 \\
\hline & Sig. &, 000 \\
\hline
\end{tabular}

KMO and Bartlletts test ( mesoprosopic )

\begin{tabular}{|c|c|c|}
\hline \multicolumn{2}{|c|}{ Kaiser-Meyer-Olkin Measure of Sampling Adequacy. } & .612 \\
\hline \multirow[t]{3}{*}{ Bartlett's Test of Sphericity } & Approx. Chi-Square & 98,326 \\
\hline & df & 36 \\
\hline & Sig. & .000 \\
\hline
\end{tabular}

KMO and Bartlletts test ( leptoprosopic )

\begin{tabular}{|l|r|r|}
\hline Kaiser-Meyer-Olkin Measure of Sampling Adequacy. &, 692 \\
Bartletts Test of Sphericity & Approx. Chi-Square & 89,113 \\
& df & 36 \\
\hline & Sig. &, 000 \\
\hline
\end{tabular}

Sumber: SPSS

Tabel 11. Rotated component matrix rectangle di tiga tipe wajah

\begin{tabular}{|c|c|c|c|}
\hline factor rotation ( & uryp & & \\
\hline Rotated Com & onent & Matrix & \\
\hline & & mpone & \\
\hline & 1 & 2 & 3 \\
\hline canggung_nyamar & .010 & .846 & .186 \\
\hline bodon_pintar & .676 & .283 & -.010 \\
\hline kasual_formal & .514 & .447 & -196 \\
\hline bohong_jujur & .565 & .016 & 500 \\
\hline rumit_sederhana & 1111 & .715 & -.121 \\
\hline kasar_halus & -.203 & -148 & .741 \\
\hline egois_peduli & 040 & 258 & .782 \\
\hline lembut_tegas & .732 & - 147 & -.258 \\
\hline lamban_cekatan & .649 & -259 & .088 \\
\hline
\end{tabular}

\begin{tabular}{|c|c|c|c|}
\hline \multicolumn{4}{|c|}{ actor rotation ( mesoprosopic ) } \\
\hline & onent $\mathrm{Me}$ & npone & \\
\hline & 11 & 2 & \\
\hline nggung_nyaman & 144 & ,025 & \\
\hline Dodon_pintar & .593 & & .129 \\
\hline 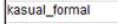 & .514 & .092 & \\
\hline Inong_ujur & 108 & .717 & -.27 \\
\hline umit_sederhana & 111 & .623 & \\
\hline ar_na & -568. & .555 & 173 \\
\hline egois_pedull & .255 & .794 & \\
\hline mbut_teg & 671 . & -257 & .355 \\
\hline loan_cek & & .108 & $.08:$ \\
\hline
\end{tabular}

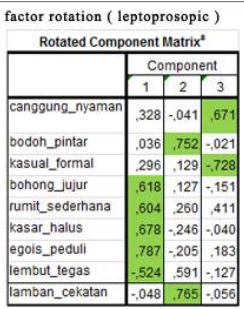

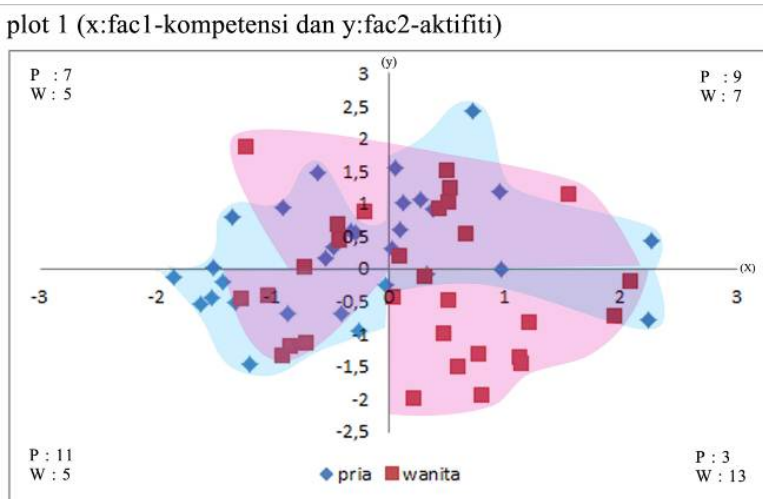

plot 2 (x:fac1-kompetensi dan y:fac 3-empati)

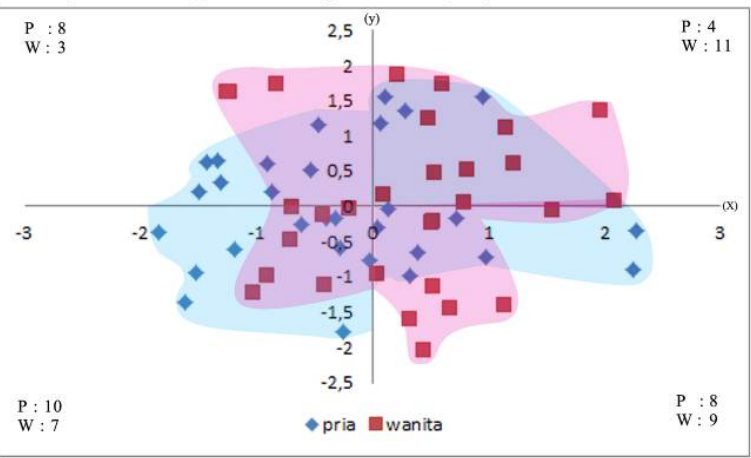

Gambar 9. Plot matrix pada persepsi kacamata rectangle di tipe wajah euryprosopic (Sumber: Penulis).

Pada Tabel 10 terlihat nilai KMO pada hasil kuesioner kacamata rectangle di tiga tipe wajah meliputi: 0,583, 0,612, dan 0,692. Karena nilai KMO $>0,5$ maka menunjukkan sampling mencukupi dan korelasi antara pasangan variabel dapat diterangkan oleh variabel lainnya.

Tabel 11 menunjukkan hasil rotasi component matrix menggunakan metode rotasi varimax. Terdapat 3 faktor baru yang saling berkorelasi antara setiap variabel. Faktor baru yang terbentuk pada kacamata rectangle kemudian diberi nama menjadi: faktor kompetensi, empati, dan aktifiti. Pemberian nama ini untuk mempermudah interpretasi. Setiap faktor baru ini kemudian dipetakan kedalam bentuk plot matrix menggunakan nilai regressi dari setiap variabel. Sehingga dapat terlihat konsentrasi persebaran persepsi kacamata pada wilayah matrix.

Pada Gambar 9, persepsi wanita pada faktor kompetensi lebih dominan di wilayah positif sedangkan faktor empati dan faktor aktifiti lebih dominan di wilayah negatif. Persepsi pria pada faktor kompetensi, dan empati lebih dominan di wilayah negatif sedangkan faktor aktifiti lebih dominan di wilayah positif. Kedua gender menunjukkan persepsi

Sumber: SPSS 
yang kurang ideal pada kacamata rectangle di tipe wajah euryprosopic.

Pada Tabel 12 ditunjukan persepsi setiap gender pada kacamata rectangle di tipe wajah euryprosopic. Tanda $(+)$ menjadi indikasi bahwa persepsi cenderung berada di wilayah positif / persepsi bersifat baik, sedangkan (-) menjadi indikasi berada di wilayah negatif / persepsi bersifat buruk.

Sehingga pada Gambar 10 dapat disimpulkan bahwa persepsi yang terbentuk pada kacamata rectangle di tipe wajah euryprosopic cenderung kurang ideal dalam membentuk citra kepemimpinan. Wanita menilai bahwa kacamata rectangle pada wajah euryprosopic membentuk citra pemimpin yang kompeten namun cenderung apatis dan pasif, sedangkan pria menilai bahwa citra pemimpin yang terbentuk cenderung aktif namun amatir dan apatis. Sehingga dapat disimpulkan bahwa kedua gender menilai kacamata di tipe wajah ini cenderung memunculkan citra apatis. Proses ini kemudian diberlakukan pada lima jenis kacamata lainnya sehingga dapat diketahui persepsi jenis kacamata pada setiap tipe wajah.

Gambar 11 menunjukkan persepsi enam jenis kacamata di wajah euryprosopic. Berdasarkan persepsi gender, terdapat tiga jenis kacamata yang ideal dalam membentuk citra kepemimpinan, yaitu kacamata oval, round, dan square. Wanita memiliki persepsi ideal pada kacamara round dan square, sedangkan pria pada kacamata oval dan round. Persepsi gender pada kacamata di wajah euryprosopic menunjukkan bahwa kedua gender menilai kacamata rectangle, $D$-shaped, dan cat eye tidak ideal di tipe wajah ini.

Gambar 12 menunjukkan persepsi enam jenis kacamata di wajah mesoprosopic. Berdasarkan persepsi gender, terdapat empat jenis kacamata yang ideal dalam membentuk citra kepemimpinan, yaitu kacamata rectangle, cateye, oval, dan round. Wanita memiliki persepsi ideal pada kacamara rectangle, cateye, oval, dan round sedangkan pria hanya pada kacamata round. Persepsi kacamata di wajah mesorosopic menunjukkan bahwa gender wanita lebih banyak menilai kacamata ideal, sedangkan pria lebih banyak menilai kacamata tidak ideal / netral.

Tabel 11. Hasil plot matrix pada kacamata rectangle di tipe wajah euryprosopic

\begin{tabular}{cccc}
\hline Gender & Kompetensi & Empati & Aktifiti \\
\hline Pria & $(-)$ & $(-)$ & $(+)$ \\
Wanita & $(+)$ & $(+)$ & $(-)$ \\
\hline
\end{tabular}

Sumber: Penulis

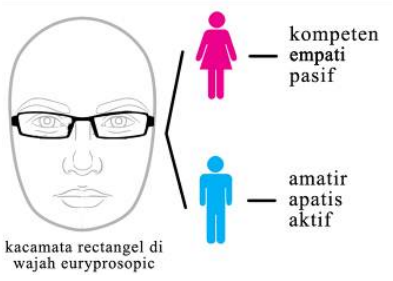

Gambar 10. Persepsi gender pada kacamata rectangle pada wajah euryprosopic (Sumber: Penulis)

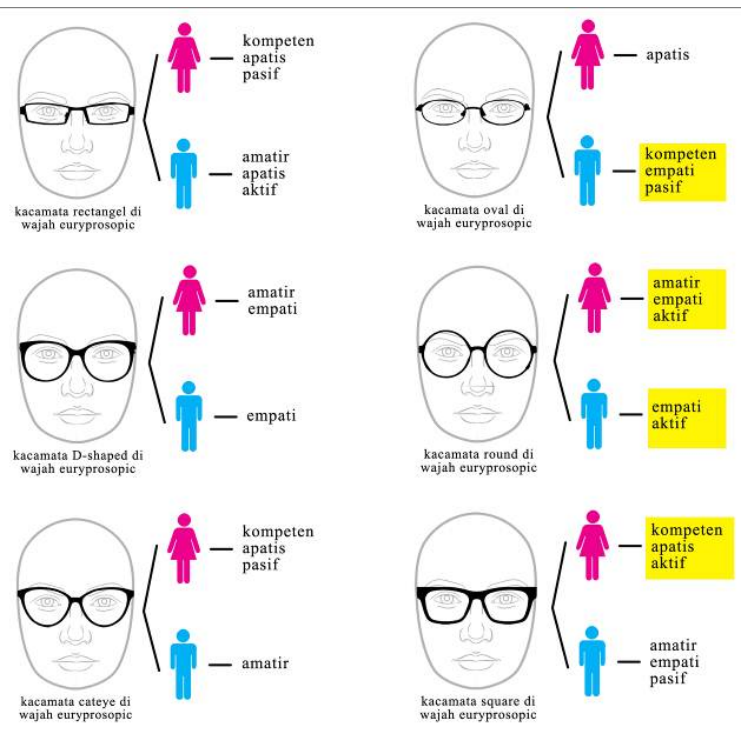

Gambar 11. Persepsi 6 jenis kacamatapada wajah euryprosopic (Sumber: Penulis)
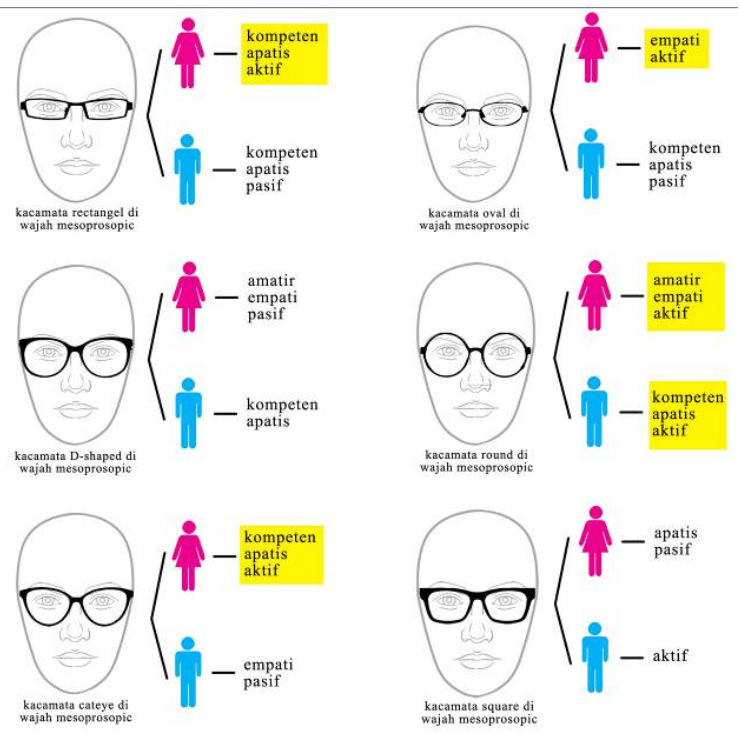

Gambar 12. Persepsi 6 jenis kacamatapada wajah mesoprosopic Sumber: Penulis. 
Abbyzar Raffi Hernawan, Achmad Syarief

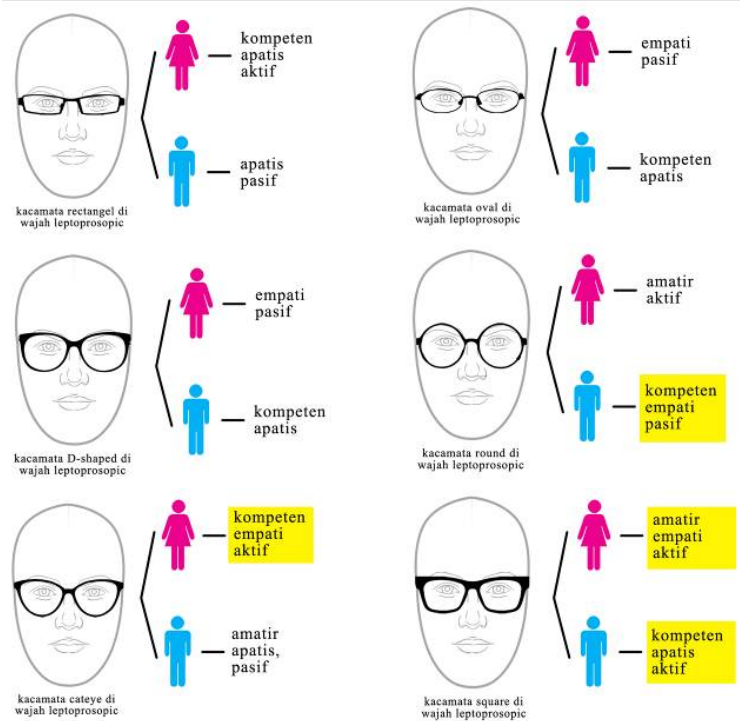

Gambar 13. Persepsi 6 jenis kacamatapada wajah leptoprosopic (Sumber: Penulis).

Gambar 13 menunjukkan persepsi enam jenis kacamata di wajah leptoprosopic. Berdasarkan persepsi gender, terdapat tiga jenis kacamata yang ideal dalam membentuk citra kepemimpinan, yaitu kacamata cateye, round, dan square. Wanita memiliki persepsi ideal pada kacamara cat eye dan square sedangkan pria pada kacamata round dan square. Persepsi kacamata di wajah leptoprosopic menunjukkan bahwa kedua gender lebih banyak menilai kacamata tidak ideal / netral.

\section{Kacamata dan citra kepemimpinan caleg}

Citra pemimpin yang terbentuk dari penggunaan kacamata rectangle adalah citra pemimpin yang kompeten namun apatis dan pasif. Persepsi kacamata rectangle di tiga tipe wajah menunjukkan bahwa persepsi cenderung negatif di semua tipe wajah.

Citra pemimpin yang terbentuk dari penggunaan kacamata D-shape di kedua gender memiliki perbedaan. Pria menilai citra pemimpin yang terbentuk adalah kompeten dan apatis, sedangkan wanita menilai citra pemimpin yang terbentuk adalah amatir, empati dan pasif. Persepsi kacamata $D$ shaped di tiga tipe wajah menunjukkan bahwa persepsi cenderung netral di semua tipe wajah.

Citra pemimpin yang terbentuk dari penggunaan kacamata cateye di kedua gender memiliki perbedaan. Pria menilai citra pemimpin yang terbentuk adalah amatir dan pasif, sedangkan wanita menilai citra pemimpin yang terbentuk adalah kompeten, apatis dan aktif. Persepsi kacamata cateye di tiga tipe wajah menunjukkan bahwa persepsi cenderung positif di tipe wajah mesoprosopic.

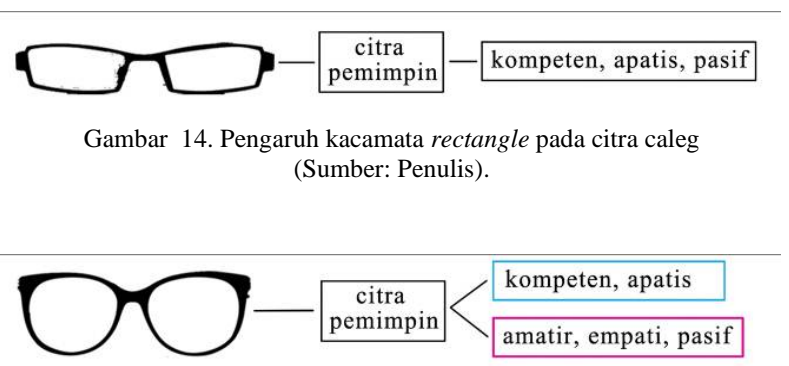

Gambar 15. Pengaruh kacamata D-shaped pada citra caleg (Sumber: Penulis).

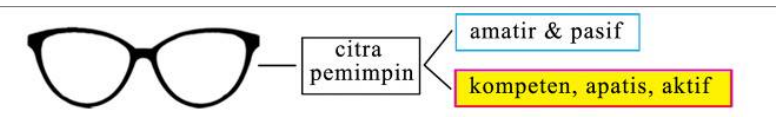

Gambar 16. Pengaruh kacamata cateye pada citra caleg (Sumber: Penulis).

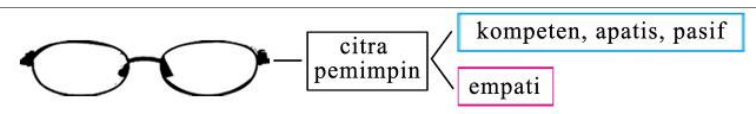

Gambar 17. Pengaruh kacamata oval pada citra caleg (Sumber: Penulis).

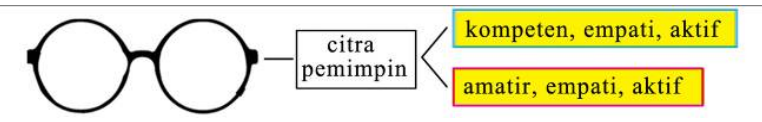

Gambar 18. Pengaruh kacamata round pada citra caleg (Sumber: Penulis).

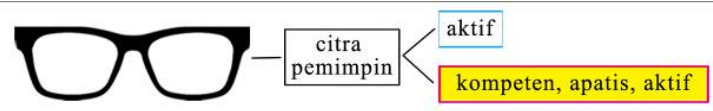

Gambar 19. Pengaruh kacamata square pada citra caleg (Sumber: Penulis).

Citra pemimpin yang terbentuk dari penggunaan kacamata oval di kedua gender memiliki perbedaan. Pria menilai citra pemimpin yang terbentuk adalah kompeten, apatis, dan pasif , sedangkan wanita menilai citra pemimpin yang terbentuk adalah empati. Persepsi kacamata oval di tiga tipe wajah menunjukkan bahwa persepsi cenderung positif di tipe wajah mesoprosopic.

Citra pemimpin yang terbentuk dari penggunaan kacamata round di kedua gender memiliki perbedaan. Pria menilai citra pemimpin yang terbentuk adalah kompeten, empati, dan aktif, sedangkan wanita menilai citra pemimpin yang terbentuk adalah amatir, empati dan aktif. Persepsi kacamata round menunjukkan bahwa persepsi cenderung positif di semua tipe wajah. 
Citra pemimpin yang terbentuk dari penggunaan kacamata square di kedua gender memiliki perbedaan. Pria menilai citra pemimpin yang terbentuk adalah aktif, sedangkan wanita menilai citra pemimpin yang terbentuk adalah kompeten, apatis dan aktif. Persepsi kacamata square di tiga tipe wajah menunjukkan bahwa persepsi cenderung positif di tipe wajah leptoprosopic

\section{Kesimpulan}

Persepsi gender terhadap Jenis kacamata yang ideal dalam membentuk citra kepemimpinan adalah kacamata dengan karakteristik frame lebar, Sedangkan mayoritas kacamata yang kurang ideal adalah kacamata dengan frame sempit. Persepsi ideal wanita lebih banyak daripada pria. Hal ini menunjukkan bahwa persepsi kacamata pada wanita lebih bervariatif dan positif.

Pembentukan citra kepemimpinan caleg dapat dibantu dengan menggunakan kacamata, Aspek bentuk kacamata, tipe wajah, dan gender mempengaruhi jenis citra kepemimpinan yang terbentuk. Frame jenis round dan tipe wajah mesoprosopic dipersepsi paling ideal dalam membentuk citra kepemimpinan oleh kedua gender.

Secara keseluruhan, kacamata dapat membentuk citra yang positif dan negatif tergantung dari kombinasi antara bentuk kacamata, tipe wajah, dan jenis gender yang mempersepsikannya. Penelitian Semantika kacamata pada pencitraan kader politik ini dapat dijadikan sebuah acuan bagi tim sukses politik untuk membentuk citra pemimpin yang ideal pada kadernya.

\section{Daftar pustaka}

Elman, D. (1977). Physical characteristics and the perception of masculine traits. The Journal of Social Psychology, 103(1), 157-158.

Indriantoro, N dan Supomo,B. (1999). Metodologi penelitian dan bisnis. Yogyakarta :BPFE Yogyakarta.

Krippendorf , K. (2006). The semantic turn: A new Foundation for design. Boca Raton , Fl: CRC

Martin R. Lehrbuch (1928). Der Anthropologie. Zurich: Systematicher darstellung

Thornton, G. R. (1943). The effect upon judgments of personality traits of varying a single factor in a photograph. The Journal of Social Psychology, 18(1), 127-148

Terry, R. L., \& Krantz, J. H. (1993). Dimensions of Trait Attributions Associated with Eyeglasses, Men's Facial Hair, and Women's Hair Length. Journal of Applied Social Psychology, 23(21), 1757-1769.

Tubbs, L Stewart dan Sylvia Moss. (1996). Human Communication: Prinsip-Prinsip Dasar. Bandung: PT. Remaja Rosdakarya

Umar, Husein. (2003). Metodologi Penelitian: Aplikasi dalam Pemasaran. Jakarta: Gramedia Pustaka Utama 